\title{
The impact of innovation and innovation subsidies on economic development in German regions
}

\author{
Uwe Cantner ${ }^{1,2}$, Eva Dettmann ${ }^{3}$, Alexander Giebler ${ }^{3}$, Jutta Günther ${ }^{4}$, Maria Kristalova ${ }^{1,4}$ \\ ${ }^{1}$ Friedrich-Schiller University Jena, Germany \\ ${ }^{2}$ University of Southern Denmark, Denmark \\ ${ }^{3}$ Halle Institute for Economic Research, Germany \\ ${ }^{4}$ University of Bremen, Germany
}

Corresponding author: Jutta Günther, University of Bremen, Email: jutta.guenther@unibremen.de; phone: +4942121866632

\begin{abstract}
Public innovation subsidies in a regional environment are expected to unfold a positive economic impact over time. The focus of this paper is an assessment of the long-run impact of innovation and innovation subsidies in German regions. We scrutinize this by an estimation approach combining panel model and time series characteristics and using regional data for the years 1980 to 2014. The results show that innovation and innovation subsidies in the long run have a positive impact on the economic development of regions in Germany. This supports a long-term strategy for regional and innovation policy.
\end{abstract}

Keywords: Public funding, innovation, regional development, Germany

JEL classification: $\mathrm{O} 30, \mathrm{O} 10, \mathrm{O} 18$

Publication information: This article was published as Uwe Cantner, Eva Dettmann, Alexander Giebler, Jutta Guenther \& Maria Kristalova (2019) The impact of innovation and innovation subsidies on economic development in German regions, Regional Studies, 53:9, 1284-1295, DOI: $\underline{10.1080 / 00343404.2019 .1639656}$ 


\section{Introduction}

Research and innovation activities undertaken by private firms play an important role for economic growth. New products and production processes contribute to competitiveness and economic development not only at the firm level, but also at the country level. Endogenous growth theory shows that spillovers from private research and innovation investment are crucial for long term economic development (Grossman and Helpman, 2001; Romer, 1986; Romer, 1990).

It is not just firms and economies that benefit from private research and innovation, the regions where the technological activities are located also benefit (Cooke et al., 2011). Because regional innovation activity and economic performance are subject to evolutionary development, these processes are neither linear nor predictable. In order to analyze such evolutionary processes, a coevolution approach has been incorporated in innovation literature. This approach originates in evolutionary economics and organizational theory and implies a bidirectional causality and co-dynamic change (Lee, 2012; Lynskey, 2006; Norgaard, 1994; van de Ven and Garud, 1994; Volberda and Lewin, 2003). This concept is especially helpful when considering regional innovation systems' long-term development.

Dynamic developments take place over time within and across regions and shape their structural and economic performance. For European regions, we know from the literature that economic performance is positively associated with research and innovation activity, and is also affected by socio-economic and institutional settings (Bilbao-Osorio and Rodriguez-Pose, 2004; Rodríguez-Pose and Crescenzi, 2008). Policy makers are well aware of the important role that innovative business activity plays in regional economic development. The European Union's introduction of a Cohesion policy and Smart Specialization as a regional development strategy includes a particular focus on regions' innovative specialization advantages (Capello and Kroll, 
2016; Foray, 2015). This underlines the importance of regional characteristics and institutions for economic performance.

Research and innovation activities of private actors are typically supported through public money to reduce the high risk associated with it and to stimulate private research and innovation. Government funding for private research and innovation activities has increased in nearly all economically advanced countries over the last years. Various direct and indirect instruments are used, such as project funding, loans, public procurement or tax reliefs to stimulate private research and innovation. According to the OECD, in most countries $10 \%$ to $25 \%$ of private research expenditure is covered by public money (OECD, 2016).

In countries with a federal structure like Germany, much of the subsidized research and innovation activities are carried out within a federally coordinated strategy of regional development. After reunification there was an increased need to adjust policies between the Eastern and Western parts of the country. Since the 1990s, a lot of attention has been given to cluster and regional agglomeration strategies in research and innovation in large scale competition programs (Eickelpasch and Fritsch, 2005).

For German regions, there are quite a few program evaluations presented as either descriptive analyses or case studies. These evaluations are based on literature stemming from academic research, as well as funding statistics and program specific surveys of the beneficiaries (e.g. Fiore et al., 2011; Kaufmann and Tödtling, 2002). In addition, there is a number of microeconometric studies dealing with the impact of innovation subsidies on technological and economic performance, and that analyze the short-term impact of innovation subsidies on regions and individual actors (Broekel, 2015; Broekel et al., 2017; Schwartz et al., 2012).

However, inventive activities are not only risky in general, but also uncertain with respect to their economic effectiveness in the long run. It is this long-run regional perspective that has been largely neglected in policy impact analyses. Therefore, in this paper we go beyond existing 
studies and analyze whether innovation activity and innovation subsidies have a positive longterm effect on regional economic development in Germany. This objective requires an estimation approach suitable for a long time period and heterogeneous panels accounting for regional characteristics. Because the period up to the end of the 1970s (known as the "German economic miracle") was much more characterized by investments in infrastructure and capital than in technology (Audretsch and Lehmann, 2016), we begin our analysis in 1980, which marks the beginning of increased technological progress and expansion of technology and innovation policy.

To the best of our knowledge, this paper is the first that applies panel estimation techniques that consider non-stationarity within a long-run impact assessment of innovation subsidies at the regional level. We concentrate on direct project funding that is targeted and applied to marketoriented innovations. Since our impact analysis begins in 1980, we also contribute to the abovementioned evaluation studies by taking a longer-term perspective.

One reason that no empirical studies on long-term regional impact exist is probably related to the fact that appropriate data was hardly available. Reliable and uniform datasets covering long time periods that deal with subsidization and innovation are needed at the regional level. One of the contributions of this paper is to compile this information from different sources and put it together as an exclusive regional panel database. Further, the study makes use of a methodical tool that allows us to capture the long-term effects within a non-stationary dynamic panel analysis.

The paper is organized as follows. In the next section we derive our research questions based on a literature review. We then introduce the data and indicators used in the empirical study (Section 3), and describe the empirical framework (Section 4). Section 5 presents the empirical results, followed by a concluding section that includes a summary and discussion.

\section{Literature review and subject of analysis}


Innovation-growth nexus

The innovation-growth nexus is a typical macroeconomic topic. Originally, macroeconomic growth models showed that long-run growth depends on capital and labor, while technology was considered to be completely exogenous. Based on the pioneering work of Romer (1986) and Lucas (1988), however, it is now widely acknowledged that technological change is an endogenous factor of the production function. The literature on endogenous growth models has been followed by numerous empirical studies analyzing the impact of R\&D expenditures on total factor productivity growth. There is plenty of empirical evidence that $R \& D$ and innovation have a positive impact on total factor productivity (e.g. Lopez-Rodriguez and Martinez-Lopez, 2017; Mohnen and Hall, 2013). There also is empirical evidence showing the causal relationship between innovation and economic growth (e.g. Guloglu and Tekin, 2012), as well as evidence that better institutions are able to amplify the positive impact of R\&D spending on productivity growth (Égert, 2016).

Estimation techniques based on time series analyses are frequently used in macroeconomic growth literature, and are the tool of choice when analyzing long-term relationships between technological change and economic development. In our paper, however, since we acknowledge the importance of regional innovation system characteristics on the one hand, and the regional orientation of innovation policy design on the other hand, we are interested in a smaller level of aggregation. In the following, we will outline the literature that highlights the importance of regions, and then apply a time series estimation technique that has not been frequently used in our context.

Regions as an effective space for innovation activity

Innovation is often a geographically bounded phenomenon, taking place within regional innovation systems (Asheim et al., 2019). Thereby, the interaction of innovating actors plays a 
crucial role (Broekel et al. 2015; Fritsch, 2004), and geographic proximity matters for synergistic effects to take place (Audretsch and Feldman, 1996). The positive effects created by regional agglomeration are typically associated with the work of Marshall (2013), and in this context positive externalities accrue to other actors in production, as well as those in research and innovation activities (Saxenian, 2000).

The regional concentration of research and innovation is also often associated with the nature of knowledge. Pure information is relatively easy to codify and transfer, but knowledge also has a tacit dimension (Polanyi, 1966). Knowledge based on experience, creativity, and innovative work depends strongly on individuals and their interaction (Azagra-Caro et al., 2017; Cowan, 2000).

It is not only geographically proximate actors with their technological capability and interaction that matter for the success of innovation activity, regional characteristics and institutions also play a crucial role (Brenner and Broekel, 2011; Cantner et al., 2018). This is where research and innovation policy comes into play as an important factor in creating a fertile ground for regional innovative businesses.

Studies on innovation subsidies

Subsidization of private research and innovation is normally justified through market failure and positive technology spillovers (Edler and Fagerberg, 2017; Mazzucato and Semieniuk, 2017). Although, immediate recipients are usually individual firms, additional positive effects occur at the aggregate level as well.

There is much empirical evidence on the positive effects of innovation subsidies on the economic performance at the country level (e.g. Montmartin and Herrera, 2015). Other empirical studies use micro data and deal with the question of whether subsidies stimulate or crowd out private research (e.g. Aristei et al. 2017; Marino et al., 2016). There is still no clear 
answer to this enigma, and a recent literature overview by Becker (2015) reveals inconsistent findings. There does, however, seem to be a shift from the earlier findings of a crowding-out effect of public funding towards more recent findings that subsidies typically stimulate private R\&D. For Germany, several micro level studies confirm positive innovation and performance effects of public subsidies in the short run (Aerts and Schmidt, 2008; Schwartz et al., 2012).

Other studies assess innovation subsidies within regions using micro data. Kaufmann and Tödtling (2002) highlight the importance, but also the deficiencies of innovation support for small and medium-sized firms in Upper Austria. Cannone and Ughetto (2014) use individual data from an innovation subsidy program of the Piemont region in Italy. They analyze the expost efficacy of the funding program and do not find any impact on firm profitability, although subsidized firms experience an increase in indebtedness and total fixed assets. Fiore et al. (2011) provide an in-depth insight into the role of innovation policy for the region of Apulia in Southern Italy where globalization presents a particular challenge for innovative competitiveness.

More insightful for our purpose are evaluation studies where regions exposed to national research and innovation subsidies are the subject of analysis. Broekel (2015) provides empirical evidence that subsidization of cooperative $R \& D$ activities has a significantly positive effect on innovation efficiency of German regions. The panel data analysis also reveals that regions with weak technological capability require a different combination of actors with respect to type and proximity in order to be successful. This indicates the need for differentiated regional strategies. Furthermore, in a related study, Broekel et al. (2017) show that cooperative R\&D is particularly effective in the context of "related variety", and when a region is centrally located in a crossregional knowledge network.

Subject of analysis 
From the theoretical and empirical literature, we know that innovation drives economic performance and that subsidies can be expected to support this relationship because they abolish market failure and contribute to spillover effects. Existing studies on the evaluation of research and innovation subsidies mentioned in the previous subsection mostly focus on rather shortterm firm-level effects. They investigate the impact of subsidies on firms' private research investment and innovative performance. Only a few empirical analyses have been conducted at the regional level (e.g. Broekel et al., 2017) despite the fact that regions play an important role as effective space for technological activity and as a target for innovation policy. We presume that the technological capability of a region and innovation expenditures, more precisely innovation subsidies, have a positive effect on economic performance over time. This positive effect should be visible primarily within a geographically bounded space that contains the regional innovation system. Therefore, our subject of analysis is the economic development in spatial planning regions (ROR).

Last but not least, our research question is driven by a desire to develop an empirically based foundation that has the potential of providing advice for policymakers. The question of whether regionally targeted innovation subsidies contribute to regional development in the long run is not a standard policy evaluation topic. The study rather gives a more general insight for policymakers in that it proves/examines if the presumed mutual interdependencies of the development of innovations and innovation subsidies really exist, and if these joint development paths have an influence on regional economic growth.

This paper aspires to add to the existing literature by analyzing the long-term effects of technological capability and innovation subsidies on the economic performance of regions based on an innovative dataset combining indicators from different fields of the economy. While Germany is a particularly suitable case because of its federal structure and increasing engagement in regionally targeted innovation policy beginning in the 1980s (Anderton, 2017; 
Broekel, 2015; Muller et al., 2017), the historical reality of the division and re-unification of Germany creates certain complications at the regional level. To gain meaningful insights on our subject, the long-run impact of innovation and innovation subsidies, it is important to include regions that were exposed to a common economic and political system or institutional environment over the entire observation period. Although there is recent evidence in the literature on the clear-cut persistence of entrepreneurship or innovation patterns at the regional level (Fotopoulos and Storey, 2017; Fritsch and Wyrwich, 2014, 2019), we consider the economic situation in the analyzed regions at the beginning of the 1980 s as given, and use it a starting point of the analysis. We run our empirical analysis for West German spatial planning regions only. We will explain in more detail below, apart from context-related realities, why it is not possible to include East German regions for the entire observation period.

\section{Data}

In order to analyze the long-term effect of technological capability and innovation subsidies, we need information about different aspects of the economic behavior of the firms and regions. The unit of analysis in this paper is the planning regions in West Germany (RORs), and is based on observations for the years 1980 to 2014 . Out of the total number of 96 planning regions in Germany, 75 are located in West Germany. In order to establish consistency in data and framework conditions, only West German planning regions are the subject of our analysis. ${ }^{\mathrm{i}}$ RORs are administratively and functionally defined by the Federal Institute for Research on Building, Urban Affairs, and Spatial Development in Germany, using information on the commuting activities of employees. The size of the planning regions falls between NUTS-2 and NUTS-3, and two to five counties are combined in the creation of each ROR.

The panel dataset is an exclusive combination of indicators from multiple sources. Information on public innovation subsidies stems from public funding statistics (Förderkatalog). The most important funders of the German government, i.e., the Federal Ministry of Education and 
Research, the Federal Ministry of Economics, and the Federal Ministry of Environment, report their project-based funding statistics to this source. All projects are assigned to policy fields within the database. For this paper, we include all projects belonging to the field "technology and innovation support" (117,387 projects). Most beneficiaries are private firms, absorbing $42 \%$ of the innovation subsidies, followed by universities (26\%), public research institutes such as Fraunhofer, Max Planck Institutes etc. (30\%), and others (3\%). Technology and innovation programs run by the above-mentioned ministries predominantly focus on applied marketoriented innovation. For policymakers, these programs that are close to market application are expected to be effective for growth and employment in the long run. The database, which is continuously updated, is used to generate information on the total amount of project funding that flows into a planning region, independent of the deeper funding philosophy, technology field, etc. ${ }^{\text {ii }}$ Institutional funding of universities and research institutes and the funding of basic research projects are not included. ${ }^{\text {iii }}$

Patent information, as a frequently used proxy for regional innovative activity (Jaffe and Trajtenberg, 2002; Verhoeven et al., 2016), is derived from the PATSTAT database (edition Autumn 2017). In our operationalization of innovation activity, patent applications at the European Patent Office (EPO) are counted based on the location of the inventor (regional creation). By doing so, we make sure that the technological activity is precisely counted at the location from which it derives. An alternative would be to count patents according to the address of the applicant, but this would lead to an overestimation of technological activity in regions that host relatively large number of headquarters and administrative centers. While we recognize the limitations of patent indicators, especially the fact that industries have a different propensity to patent and that large and small firms have different patenting strategies, there are still a number of advantages of using patent data as a proxy for innovation (Abbas et al., 2014; Kim and Lee, 2015). 
Human capital and information on entrepreneurial activity are taken from the Establishment History Panel (BHP) of the Institute for Employment Research (IAB). Table 1A in the appendix provides an overview of the variables, their operationalization and source.

The empirical study focuses on the analysis of 75 West German planning regions. Table 2A in the Appendix summarizes key descriptive statistics of the panel data set. The data shows that there are strong regional disparities with respect to the variables included. While a region on average receives about 17 Euro innovation subsidies per capita across all years, some regions receive up to 476 Euro per year (e.g. Middle Upper Rhine) and others less than 0.1 Euro per year (e.g., some Northern regions like the area surrounding Bremen, Emsland or the East of Friesland). After 2006, all regions were subsidized with more substantial amounts.

Similarly, there are significant differences in innovation performance. On average, there are 2.23 patent applications per 10,000 inhabitants across all regions and years. But the range across regions varies between 0.013 (South-West Schleswig-Holstein in 1980) and 9 (HochrheinBodensee in 2006 and Munich in 2001). Looking at between-group and within-group statistics, some variables display higher variation across regions, while others vary more across time. For instance, GDP, entrepreneurial activity as well as innovation activity shows higher variation across regions than across time, suggesting that catching up is hard to achieve.

Maps 1 and 2 illustrate the innovative activity and the public innovation subsidies per capita in all West German regions for the year 2014. The maps show that while innovative activity is relatively more prevalent in the Southern regions, the distribution of innovation subsidies shows no clear North-South divide. ${ }^{\text {iv }}$ When comparing the maps, we observe that some of the most innovative regions are also very successful in attracting subsidies. This is especially true for Munich, which ranks first in patents and subsidies throughout time. Other regions (Rheinpfalz, Schwarzwald-Baar-Heuberg, and Bielefeld) show a relatively strong performance in terms of patents, however, subsidies are not substantial. Yet other regions (Dortmund, Braunschweig, 
Bremen, and Saar) attract considerable subsidies, but perform poorly in terms of the number of patents. Although there are any number structural reasons underlying this regional variation, we can conclude from our long-term observation that high subsidies are not necessarily strongly related to innovation (patents). This is clearly expressed in the relatively low correlation coefficient of about 0.3 .

\section{Map 1: Number of patents with at least one German applicant per inhabitant in the} planning regions in West Germany in the year 2014

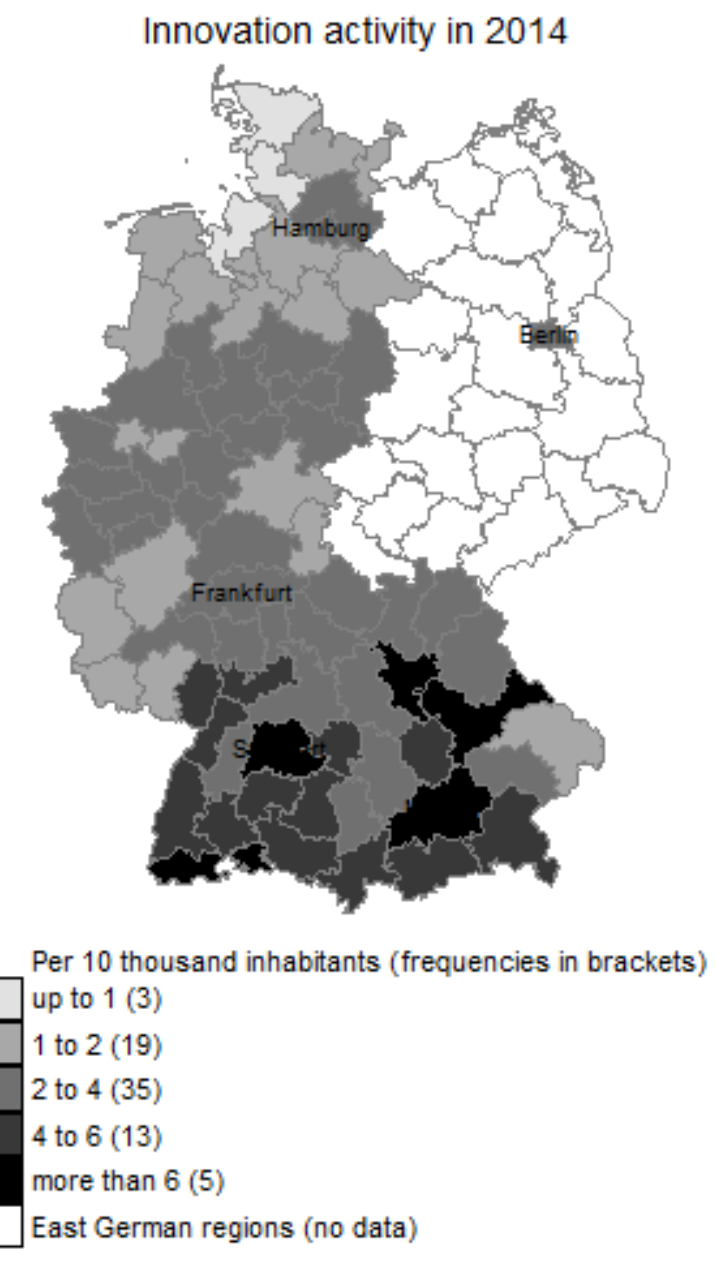

Source: PATSTAT, Cambridge Econometrics. Own calculations.

Note: The figures in brackets indicate the number of regions belonging to the relevant category. 
Map 2: Public innovation subsidies in real prices per capita in the planning regions in West Germany in the year 2014

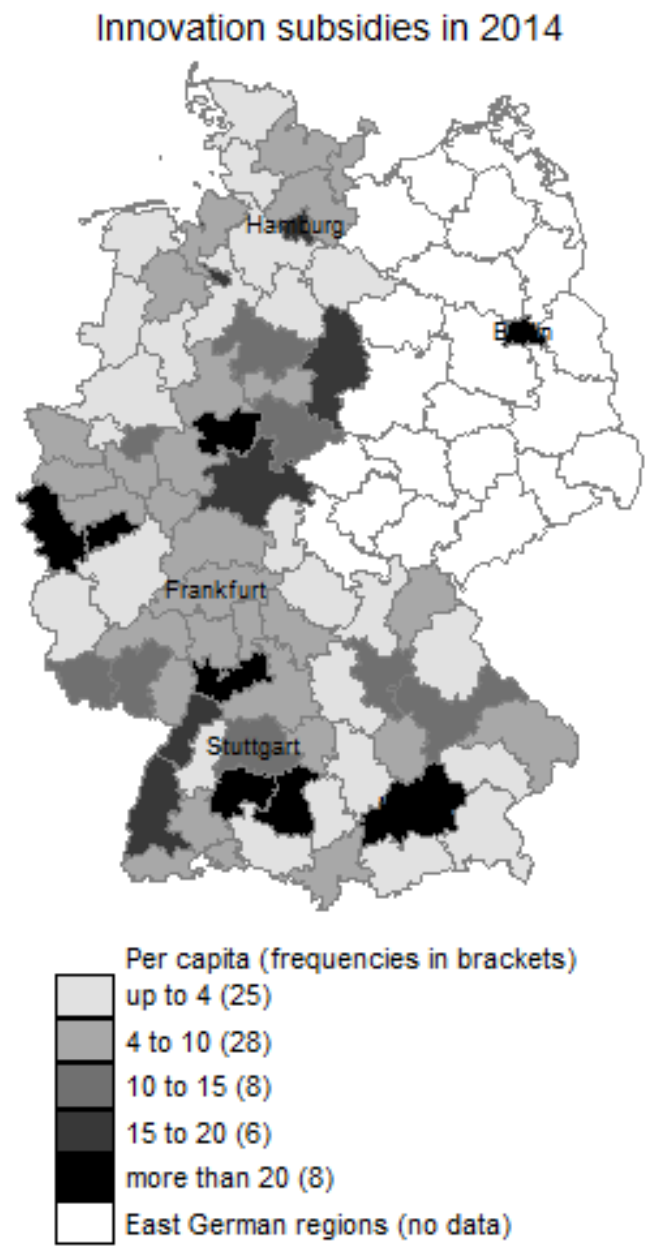

Source: Förderkatalog, Cambridge Econometrics. Own calculations.

Note: The figures in brackets indicate the number of regions belonging to the relevant category.

Tables $3 \mathrm{~A}$ and $4 \mathrm{~A}$ in the Appendix provide correlation matrices for all variables, comparing 1980 and 2014. For these two years, the strength of correlation has not changed much. Interestingly, the correlation between innovation subsidies and innovation lies only at around 0.3 while other relations are stronger.

Figure 1A in the appendix illustrates the development of the variables over time for selected regions. ${ }^{v}$ For most of the indicators, especially innovation subsidies per capita and innovation activity per capita, we can observe a systematic change over the observation period. In all of the regions presented in Figure 1A, innovation activity moves in a direction similar to GDP per 
capital development. The slope of innovation subsidies, however, is different (e.g., in Munich and Schleswig-Holstein Mitte). This difference begs for an investigation of potential structural long-term relationships between these two indicators.

\section{Econometric Approach}

Usually, research questions like ours are answered within the framework of causal treatment effects analysis. In this methodological framework, the causal impact of innovation subsidies on GDP would be estimated. However, this framework implies some preconditions that can hardly be fulfilled in our long-run analysis.

First, we should be able to identify and differentiate between a treatment phase and a posttreatment phase. But in our case, we observe a quasi-permanent treatment over the entire observation period with only few interruptions. Second, we would have to make sure that all other relevant influences on GDP growth are excluded. If we think, for instance, of an IV fixed effects model using innovation subsidies as an instrument for innovation activity, the region fixed effects and included variables and time dummies should capture all relevant influences on GDP growth. Considering the available data, this is difficult to ensure for our long-run analysis. Third, the data used in this paper can be characterized as a panel with a large number of regions and a large number of observation periods. Different from short term panels, one must be aware of the fact that the observed variables may dynamically change over time, meaning that we have to consider the time trends of the variables. Therefore, we use a dynamic panel model that explicitly considers time trends, or the non-stationarity, of the variables. ${ }^{\mathrm{vi}}$

One way to deal with different time trends is to separately fit the estimation model for each region and then calculate the unweighted arithmetic average of the coefficients. This estimator was proposed by Pesaran and Smith (1995), and is known as the mean-group (MG) estimator. The model applied in this paper is able to estimate non-stationary dynamic panels with heterogeneity across groups by using a pooled mean-group (PMG) estimator. This estimator 
can be thought of as a combination of pooling and averaging of coefficients (Pesaran et al., 1999), and estimates long-run coefficients common for all regions, but allows different shortrun coefficients and error variances across all groups. The PGM estimation procedure begins by estimating the long-run slope coefficients jointly across regions using a maximum likelihood procedure. This is then followed by an individual estimation of short-run coefficients that include the implementation of an error correction, regional intercepts and error variances.

The PMG estimator belongs to a set of panel co-integration techniques, and allows us to examine the dynamic co-evolvement of variables over time to determine if the variables are linked by some structural long-term relationship. In other words, the PMG extends a time series co-integration analysis to a panel data setting (Breitung and Pesaran, 2008; Johansen, 1988). The intuition is that a long-run relationship between non-stationary variables exists, because some linear combination of these non-stationary variables is stationary.

To test for consistency, we apply a Hausman test. Its null hypothesis represents the homogeneity of the coefficients in the long run. As much of the literature advocates, PMG often offers the best solution when having to trade-off between consistency and efficiency.

Consistent with the described model, we assume that the long-run relationship between regional economic performance and the explanatory variables is identical among all West German regions, but the short-run coefficients are allowed to be region-specific. This can be justified in our case by the fact that long-run regional dynamics are driven by similar processes across Germany, such as common institutions, available infrastructure and technology, but short-run dynamics might differ, e.g., due to region-specific circumstances and different regional innovation policies. ${ }^{\text {vii }}$ As a starting point, we assume the following long-run economic performance function of the regions:

$$
y_{i t}=\theta_{o}+\theta_{1} p_{i t}+\theta_{2} f_{i t}+\theta_{3} h_{i t}+\theta_{4} g_{i t}+\mu_{i}+\epsilon_{i t}
$$


where $y_{i t}$ is the regional economic performance of region $i=1,2, \ldots N$ at time $t=1,2, \ldots, T$; $p_{i t}$ is the regional innovation activity; $f_{i t}$ the public subsidy for innovation at regional level; $h_{i t}$ is the human capital in a region; $g_{i t}$ reflects the creativity of a region (entrepreneurial activity); and $\mu_{i}$ is the group-specific (regional) effect.

If the variables are $I(1)$ and co-integrated, then the error term is $I(0)$ for all regions when transferred to an individual time series setting, an Autoregressive-Distributed Lag (ARDL) specification can be derived. The dynamic panel specification of (1) that is chosen for the analysis is as follows:

$$
\begin{gathered}
y_{i t}=\delta_{10 i} p_{i t}+\delta_{11 i} p_{i, t-2}+\delta_{20 i} f_{i t}+\delta_{21 i} f_{i, t-6}+\delta_{30 i} h_{i t}+\delta_{31 i} h_{i, t-5}+\delta_{40 i} g_{i t}+ \\
\delta_{41 i} g_{i, t-4}+\lambda_{i} y_{i, t-1}+\mu_{i}+\epsilon_{i t}
\end{gathered}
$$

We presume that the included variables do not have an immediate effect on regional economic performance, but rather, that the effect occurs with variable-specific deceleration lengths. The presumed 'functional chain' can be described as follows: Innovation subsidies influence the human capital resources of the subsidized firms in the following year after the subsidization occurs, and the success of innovation activities of the firms (namely, patents) after four years, and finally, the effect on regional performance is examined with a relatively long delay of five years. ${ }^{\text {viii }}$ In order to expose any truly long-run effects and to solve any problems of potential endogeneity, we also employ an alternative lag structure with up to ten lags. The described chain of effects can be observed for the longer run lag structure as well.

The concept of co-integration is tightly connected to the idea of an error correction (Engle and Granger, 1987), because co-integrated variables respond to any deviation from the long-term equilibrium. As a result, we can express (2) as an error correction model:

$$
\begin{gathered}
\Delta y_{i t}=\phi_{i}\left(y_{i, t-1}-\theta_{o i}-\theta_{1 i} p_{i t}-\theta_{2 i} f_{i t}-\theta_{3 i} h_{i t}-\theta_{4 i} g_{i t}\right)+\delta_{11 i} \Delta p_{i t}+\delta_{21 i} \Delta f_{i t}+ \\
\delta_{31 i} \Delta h_{i t}+\delta_{41 i} \Delta g_{i t}+\epsilon_{i t}
\end{gathered}
$$


where $\phi_{i}$ is the error-correction speed of the adjustment parameter and $\theta_{\xi}$ are the long-run coefficients of our main interest. The term $\left(y_{i, t-1}-\theta_{o i}-\theta_{1 i} p_{i t}-\theta_{2 i} f_{i t}-\theta_{3 i} h_{i t}-\theta_{4 i} g_{i t}\right)$ is the so-called equilibrium error, and represents basically a reaction of the variables in the shortrun to a deviation from the long-term trend. To put it into other words, $\theta_{\xi}$ measures a long-run relationship between, for instance, innovation subsidies and economic performance, and $\phi_{i}$ shows the extent to which an occurred disequilibrium (for instance, as a result of an external shock such as a policy change) is corrected in the next period. ${ }^{\mathrm{ix}}$

To exclude problems of multicollinearity, we also estimate variance inflation factors (VIF) of all variables. The fairly low average value across all right-hand variables equals 1.78 , suggesting that the standard errors for the predictor coefficients are, on average, only $33 \%$ larger than they would be if the predictor variables were uncorrelated among each other. 


\section{Long term effects in West German regions}

Table 1 gives an overview of the unit root tests after first-differencing (i.e., removing the time trend). The results reveal that all variables are $I(1)$, which allows us to explore existing cointegration relationships in the next step.

Table 1: Panel unit root tests

\begin{tabular}{|l|l|l|l|l|l|l|}
\hline & ADF & PP & IPS & LLC & HT & Breitung \\
\hline $\begin{array}{l}\text { Economic performance } \\
\text { (GDP per capita) }\end{array}$ & $1508.6 * * *$ & $3487.9 * * *$ & $-33.1 * * *$ & & & \\
\hline $\begin{array}{l}\text { Innovation subsidies } \\
\text { (narrow sense) }\end{array}$ & $2421.9 * * *$ & $4441.3 * * *$ & $-34.2 * * *$ & & & \\
\hline $\begin{array}{l}\text { Innovation activity } \\
\text { (regional exploitation) }\end{array}$ & $1517.8 * * *$ & $3714.4 * * *$ & $-33.4 * * *$ & & & \\
\hline Human capital & $1596.8 * * *$ & $1754.4 * * *$ & $-26.0 * * *$ & $-31.8 * * *$ & $0.1 * * *$ & $-23.6 * * *$ \\
\hline Entrepreneurial activity & $2344.4 * * *$ & $4392.5 * * *$ & $-35.3 * * *$ & $-38.6 * * *$ & $-0.4 * * *$ & $-36.3 * * *$ \\
\hline
\end{tabular}

Note: ADF: augmented Dickey-Fuller inverse chi-squared; PP: Phillips-Perron chi-squared; IPS: Im, Pesaran and Chin Z-t-tilde-bar; LLC: Levin, Lin and Chu t-stat.; HT: Harris-Tzavalis rho-stat.; and Breitung lambda; *** indicates a significance level at $1 \%$; Some tests require strongly balanced data. In case this requirement is not fulfilled, the test result is not reported in the table.

In line with the methodology explained in the previous section, non-stationary dynamic heterogeneous panel models are estimated for the 75 West German RORs for the years 1980 to 2014. Justifying our lag choice by the existing empirical literature (see e.g. Bosma et al., 2018; Broekel et al., 2017; Carree and Thurik, 2008; Diebolt and Hippe, 2019), we estimate two alternative models. Our first model has a maximum lag of five, and the second model has a maximum lag of ten. The results for the equation that uses regional economic performance (GDP) as the dependent variable are reported in Table 2.

The first and fourth columns report our preferred pooled mean-group (PMG) estimator, each with a different lag structure, which imposes the above-mentioned restrictions on long-run coefficients. The second and third columns present robustness checks. The second column reports the mean-group (MG) estimator, which does not impose any restrictions, and the third column reports a dynamic fixed-effects estimator for stationary panels (DFE), which imposes the strictest restrictions (homogeneity in the slope coefficients). 
Usually, the long-run coefficients and the error correction term are regarded as the most relevant. The long-run coefficients give the long-term equilibrium relationship between the dependent variable and the analyzed explanatory factors, the error correction term predicts a speed of adjustment to the long-run trends.

For every model, we observe a highly significant error correction term. As expected, this parameter is negative, suggesting that the variables return to their long-run equilibrium. In the case of the PMG model for GDP (Table 2), a deviation from a long-term regional performance trend is corrected by at least $33 \%$ in the next period. These results show that in West German regions there is an adjustment dynamic from short-run deviations to the long-run equilibrium trends in economic performance.

For testing the hypothesis of slope homogeneity, the Hausman test is applied. The p-value for the Hausman test is in both models with a different lag structure of around 0.5 and 0.78 respectively, meaning insignificance. This confirms the hypothesis of homogeneity for the long-run coefficients in the estimated models for GDP. Thus, it is more appropriate to apply PMG rather than MG in the case of every lag structure. This is in line with our theoretical considerations. Although innovation policy is conducted in Germany at the regional level, which imply short-run differences, West German regions share a common historical legacy that makes them homogeneous in the long run.

We concentrate on interpreting the PMG coefficients in the following. The results presented in the first part of Table 2 express the long-term influence of innovation activity, innovation subsidies, human capital and entrepreneurial activity on the economic development of West German regions. GDP growth is explained to a large extent by human capital development. Human capital has the highest coefficient and remains robust when considering various lags. This is in line with our expectations and insights provided in other streams of literature (Dettmann et al., 2016; Grossman and Helpman, 2001). On the other hand, while entrepreneurial activity has no significant effect on GDP growth in the medium run (third lag), 
there is a positive effect in the long run (eighth lag). This might be because newly founded firms come across with firm exits, which is positive for innovation dynamics, but not necessarily for growth.

Our presumption that both variables, innovation and innovation subsidies, would have a positive influence on regional development in terms of GDP growth can be supported. The elasticity of innovation subsidies unfolds more noticeably when considering a larger time lag. This result might support the notion of the truly long-run nature of innovation subsidies.

The coefficient of innovation activity with a one-year lag amounts to 0.058 , and is highly significant. Blanco et al. (2016) report a nearly identical coefficient on the U.S. data within the same model setting ( 0.056 for the R\&D stock). It also falls into the same range as in the studies by Hall et al. (2010) or Bronzini and Piselli (2009) on Italian regional data.

This result is in line with the empirical literature (e.g. Bassanini et al., 2000; Guloglu and Tekin, 2012; Lopez-Rodriguez and Martinez-Lopez, 2017). Beyond this, it means that the micro level innovation efforts, which have been shown to be beneficial to the firm in existing studies (e.g. Broekel, 2015; Fiore et al., 2011; Schwartz et al., 2012), also translates into a positive economic development of the region. The findings are also in line with Brenner and Broekel (2011) who stress that regions are an important unit of analysis in innovation studies. We can conclude that the impact channels underlying macroeconomic systems are also relevant for smaller regions. Finally, we can conclude that the shift towards technology and innovation policy, which began in the 1980s, has a positive long-term influence on regional development. 
Table 2: Estimation results of different panel cointegration models for the West German planning regions (1980-2014). GDP as a dependant variable.

\begin{tabular}{|c|c|c|c|c|c|c|}
\hline & PMG & $\mathrm{MG}$ & DFE & PMG & $\mathrm{MG}$ & DFE \\
\hline $\begin{array}{l}\text { Innovation } \\
\text { subsidies (lag 5) }\end{array}$ & $\begin{array}{c}0.004 * * \\
(2.00)\end{array}$ & $\begin{array}{l}0.010 \\
(1.58)\end{array}$ & $\begin{array}{l}0.006 \\
(1.42)\end{array}$ & & & \\
\hline $\begin{array}{l}\text { Innovation } \\
\text { subsidies (lag } \\
\text { 10) }\end{array}$ & & & & $\begin{array}{c}0.007 * * * \\
(3.60)\end{array}$ & $\begin{array}{c}0.013 * * \\
(3.23)\end{array}$ & $\begin{array}{c}0.008^{* *} \\
(2.15)\end{array}$ \\
\hline $\begin{array}{l}\text { Innovation } \\
\text { activity (lag 1) }\end{array}$ & $\begin{array}{c}0.058 * * * \\
(7.27)\end{array}$ & $\begin{array}{c}0.118^{* *} \\
(2.02)\end{array}$ & $\begin{array}{c}0.060 * * * \\
(3.98)\end{array}$ & & & \\
\hline $\begin{array}{l}\text { Innovation } \\
\text { activity (lag 6) }\end{array}$ & & & & $\begin{array}{c}0.033 * * * \\
(4.58)\end{array}$ & $\begin{array}{c}0.034 * * \\
(2.05)\end{array}$ & $\begin{array}{c}0.068 * * * \\
(5.37)\end{array}$ \\
\hline $\begin{array}{l}\text { Human capital } \\
\text { (lag 4) }\end{array}$ & $\begin{array}{c}0.219 * * * \\
(23.12)\end{array}$ & $\begin{array}{c}0.165 * * \\
(3.02)\end{array}$ & $\begin{array}{c}0.218 * * * \\
(11.34)\end{array}$ & & & \\
\hline $\begin{array}{l}\text { Human capital } \\
\text { (lag 9) }\end{array}$ & & & & $\begin{array}{c}0.210 * * * \\
(22.91)\end{array}$ & $\begin{array}{c}0.238 * * * \\
(7.51)\end{array}$ & $\begin{array}{c}0.218 * * * \\
(11.80)\end{array}$ \\
\hline $\begin{array}{l}\text { Entrepreneurial } \\
\text { activity (lag 3) }\end{array}$ & $\begin{array}{l}0.005 \\
(0.54)\end{array}$ & $\begin{array}{l}0.042 \\
(1.08)\end{array}$ & $\begin{array}{l}-0.011 \\
(-0.62)\end{array}$ & & & \\
\hline $\begin{array}{l}\text { Entrepreneurial } \\
\text { activity (lag 8) }\end{array}$ & & & & $\begin{array}{c}0.025 * * * \\
(3.54) \\
\end{array}$ & $\begin{array}{l}0.026 \\
(1.63) \\
\end{array}$ & $\begin{array}{l}0.010 \\
(0.74) \\
\end{array}$ \\
\hline $\begin{array}{l}\text { Speed of } \\
\text { adjustment }\end{array}$ & $\begin{array}{c}- \\
0.354 * * * \\
(-14.41)\end{array}$ & $\begin{array}{c}-0.572 * * * \\
(-17.80)\end{array}$ & $\begin{array}{c}-0.257 * * * \\
(-17.44)\end{array}$ & $\begin{array}{c}-0.439 * * * \\
(-15.20)\end{array}$ & $\begin{array}{c}-0.772 * * * \\
(-20.16)\end{array}$ & $\begin{array}{c}-0.337 * * * \\
(-19.00)\end{array}$ \\
\hline
\end{tabular}

$\begin{array}{lccc}\text { SR Innovation } & -0.001 & -0.003 * * & -0.002 * * \\ \text { subsidies (lag 5) } & (-0.75) & (-2.63) & (-2.17)\end{array}$

SR Innovation

subsidies (lag

10)

$\begin{array}{ccc}-0.002 & -0.004 * * & 0.000 \\ (-1.41) & (-2.43) & (0.12)\end{array}$

SR Innovation $\quad 0.041 * * * \quad 0.048 * * * \quad 0.030 * * *$

activity (lag 1) (5.49) (7.48) (6.72)

SR Innovation

activity (lag 6)

$$
\begin{array}{ccc}
-0.018 * * * & -0.016 * & -0.014 * * \\
(-3.82) & (-1.87) & (-3.02)
\end{array}
$$

SR Human

capital (lag 4)

$$
\begin{array}{ccc}
- & -0.219 * * * & -0.121 * * * \\
0.190 * * * & (-6.56) & (-4.22) \\
(-6.30) & &
\end{array}
$$


SR Human

$\begin{array}{lll}0.006 & -0.013 & 0.024\end{array}$

capital (lag 9)

$\begin{array}{lll}(0.17) & (-0.28) & (0.84)\end{array}$

$\begin{array}{lccc}\text { SR } & 0.007 * * & 0.006 & 0.006 * \\ \text { Entrepreneurial } & (2.79) & (1.33) & (1.86)\end{array}$

activity (lag 3)

SR

$0.018^{* * *} \quad 0.015^{* *} \quad 0.011 * * *$

Entrepreneurial

(3.99)

(2.34)

(3.48)

activity (lag 8)

\begin{tabular}{lcccccc} 
Constant term & $\begin{array}{c}3.983 * * * \\
(14.46)\end{array}$ & $\begin{array}{c}6.366 * * * \\
(18.28)\end{array}$ & $\begin{array}{c}2.922 * * * \\
(16.85)\end{array}$ & $\begin{array}{c}4.780 * * * \\
(15.22)\end{array}$ & $\begin{array}{c}8.424 * * * \\
(20.06)\end{array}$ & $\begin{array}{c}3.818 * * * \\
(19.61)\end{array}$ \\
\hline No. of obs & 2025 & 2025 & & 1658 & 1658 & \\
BIC & -8614 & -9224 &. & -7376 &. &. \\
Log & 4345 & 4650 & & 3725 &. & \\
pseudolikelihood & & & & & \\
\hline Hausman test & 0.5257 & & & & \\
\hline
\end{tabular}


We also report short-run coefficients in Table 2, which are the mean values for 75 regionspecific coefficients. As mentioned above, in this paper we concentrate on the interpretation of the long-run results. It is, however, worth mentioning that the mean short-run coefficient for innovation subsidies is insignificant. This means that across regions, on average, subsidies have no impact in the short run after controlling for the long-run relationship. This result implies that an underlying mechanism translating innovation subsidies into economic growth is long-run in its nature.

To summarize, the results confirm the presumed existence of a long-run equilibrium in West German planning regions for the period 1980-2014. There is a positive and statistically significant relationship between the dynamics of regional economic performance in terms of GDP and the evolution of innovation activities, innovation subsidies and human capital. Most long-run elasticities (except for the human capital) exhibit relative sensitivity to the lag length. Additionally, entrepreneurial activity has a positive long-run effect on GDP growth, but only with a higher lag.

As a robustness check, further estimations are applied on an alternative lag specification and an alternative sample. ${ }^{\mathrm{x}}$ Specifically, the check is applied only to regions that exhibit substantial and permanent technological activity and continuously receive public innovation subsidies during the observation period. In this subsample, we include all West German planning regions that show above the median innovation activity (in terms of the number of patents) for at least in one year during the observation period (1980-2014). This reduces the sample to 56 regions.

The models remain robust when looking at the values of the coefficients (see Table 5A and 6A in the Appendix). The error correction term indicates more or less the same adjustment speed when compared to the entire sample. The long-run coefficient of innovation subsidies exhibits a slightly higher effect on regional economic growth. This could simply mean than more successful regions are able to attract more subsidies. 


\section{Conclusions and discussion}

The aim of this paper is to analyze the effect of innovation subsidies and innovation on regional performance in terms of GDP growth. Unlike most studies on this topic, we do not focus on the effect of one factor while controlling for the influence of other factors, rather we are explicitly interested in the joint development and mutual influences of subsidies and innovation, and their impact on regional performance. It is our opinion that the joint development (or coevolution) of these factors can be better analyzed at the regional level, in our case the RORs of West Germany. Because regions provide an environment for innovative actors who engage in innovation activity interacting with other actors within a regional innovation system, the effects of innovative activities and their support is more visible at the regional level.

Methodologically, this study has chosen to analyze coevolution by using the co-integration approach. Taking a long-term perspective, we are able to consider the presumed coevolution of subsidies, innovations and regional performance. Our results show that, with a certain time delay, innovation subsidies and innovation activities have a positive long-term impact on regional GDP. While the positive long-run effect of innovation is not surprising (especially since the time delay of the effect on the GDP is quite small), the long-term significantly positive effect of innovation subsidies is somewhat unexpected. Nevertheless, we interpret the results as confirmation for the presumed mutual influences of different factors within a region, or to put it in other words, for the coevolution of innovation subsidies and innovations and their joint impact on regional development.

Our results reveal an estimated long-term relationship between project-related innovation subsidies and innovative activities over the period from 1980 until 2014, and complement and complete the picture of how innovation subsidies are able to influence the economic growth of a region, and is an important contribution to the existing literature. This also provides interesting insights for policymakers. It appears that existing policies intended to promote a knowledge- 
based economy at the regional level are working. Also, with respect to start-up activity, our findings are rather encouraging. We show that entrepreneurial activities support regional performance in the long term.

This paper has not addressed the fact that policy design is also evolving, and is now more focused on strategic targets like cooperative innovation, clustering, or internationalization. Instead, we examine innovation subsidies as an aggregate, which is a somewhat unusual method of evaluating R\&D subsidies. In future analyses, it may be promising to take shifting paradigms of innovation policy into account when analyzing its impact on regional economic development.

Our analytical framework and dataset is not free of limitations, and this should be kept in mind when interpreting our results. First of all, there is a trade-off between the length of the observation period and the number of independent variables that can be included. For example, we were unable to find additional variables that represent institutional or systemic characteristics of a region and are consistent over time. The issue of the intra-regional spillover effects is also beyond the scope of our analysis. Patents, used as a proxy for innovation activities, represent newly created knowledge only partially, since they do not incorporate process or organizational innovation activity.

Another limitation of our analysis is that our data does not include other forms of public innovation support, such as infrastructure development in the form of technology parks or innovation agencies, institutional funding of public science organizations, initiatives of local governments etc. To include all these support mechanisms, a more comprehensive dataset would be necessary, requiring the cooperation of all relevant public authorities. Therefore, we cannot exclude that the real effects of public policy in the field of R\&D and innovation are even stronger than reported here. 
As mentioned in our introduction, our analysis is restricted to West Germany regions. Future analyses might be able to include larger datasets that comprise East German regions, making a comparative analysis of East and West Germany possible. Moreover, our analysis does not account for knowledge spillovers, a concept that is well established in the literature. Knowledge spillovers can exert a profound influence on regions that lag behind the technological frontier and economic development (Sanso-Navarro and Vera-Cabello, 2018). Applying this sort of research extension to East German regions would be especially interesting.

Finally, an interesting question for further research is to disentangle the impact channels through which innovation subsidies and innovation activity influence GDP growth and employment. Within the scope of IV models, or a systemic approach that would allow us to incorporate a more sophisticated lag structure, one could first quantify the impact of innovation subsidies on innovation activities, and then make a causal statement about how innovation activities translate into regional growth. 
Acknowledgements: We are indebted to the Institute for Employment Research for the provision of social data (Establishment History Panel) which made the empirical study possible. We greatly acknowledge comments and suggestions of the participants of scientific conferences and workshops, in particular the Heilbronn Symposium 2017, the Jena Lecture in Economic Geography 2018, and the Research Seminar of the Institute for Economic Research and Policy at the University of Bremen (ierp). Furthermore, the paper benefited strongly from comments of three anonymous referees who we would like to thank. 


\section{Reference list}

Abbas, A., Zhang, L. and Khan, S.U. (2014) 'A literature review on the state-of-the-art in patent analysis', World Patent Information, 37, pp. 3-13.

Aerts, K. and Schmidt, T. (2008) ‘Two for the price of one?' Research Policy, 37(5), pp. 806-822.

Anderton, K. (2017) 'Understanding the role of regional influence and innovation in EU policymaking: Bavaria and Cars and CO 2', Environment and Planning C: Politics and Space, 35(4), pp. 640-660

Aristei, D., Sterlacchini, A. and Venturini, F. (2017) 'Effectiveness of R\&D subsidies during the crisis: firm-level evidence across EU countries', Economics of Innovation and New Technology, 26(6), pp. 554-573

Asheim, B.T., Isaksen, A. and Trippl, M. (2019) Advanced Introduction to Regional Innovation Systems. (Elgar Advanced Introductions series). Cheltenham: Edward Elgar Publishing.

Audretsch, D.B. and Feldman, M.P. (1996) 'R\&D Spillovers and the Geography of Innovation and Production', American Economic Review, 86(3), pp. 630-640.

Audretsch, D.B. and Lehmann, E. (2016) The seven secrets of Germany: Economic resilience in an era of global turbulence / David B. Audretsch and Erik E. Lehmann. New York: Oxford University Press.

Azagra-Caro, J.M., Barberá-Tomás, D., Edwards-Schachter, M. and Tur E.M. (2017) 'Dynamic interactions between university-industry knowledge transfer channels: A case study of the most highly cited academic patent', Research Policy, 46(2), pp. 463-474.

Bassanini, A., Scarpetta, S. and Hemmings, P. (2000) OECD Economics Department Working Papers (283).

Becker, B. (2015) 'Public R\&D Policies and Private R\&D Investment: A Survey of the Empirical Evidence', Journal of Economic Surveys, 29(5), pp. 917-942. 
Bilbao-Osorio, B. and Rodriguez-Pose, A. (2004) 'From R\&D to Innovation and Economic Growth in the EU', Growth and Change, 35(4), pp. 434-455.

Blackburne, E. and Frank, M. (2007) 'Estimation of nonstationary heterogeneous panels', Stata Journal, 7(2), pp. 197-208.

Blanco, L.R., Gu, J. and Prieger, J.E. (2016) 'The Impact of Research and Development on Economic Growth and Productivity in the U.S. States', Southern Economic Journal, 82(3), pp. 914-934.

Bosma, N., Content, J., Sanders, M. and Stam, E. (2018) 'Institutions, entrepreneurship, and economic growth in Europe', Small Business Economics, 51(2), pp. 483-499.

Breitung, J. and Pesaran, M.H. (2008) 'Unit Roots and Cointegration in Panels’, in Mátyás, L. and Sevestre, P. (eds.) The Econometrics of Panel Data: Fundamentals and Recent Developments in Theory and Practice. Berlin, Heidelberg: Springer Berlin Heidelberg, pp. 279-322.

Brenner, T. and Broekel, T. (2011) 'Methodological Issues in Measuring Innovation Performance of Spatial Units', Industry \& Innovation, 18(1), pp. 7-37.

Broekel, T. (2015) 'Do Cooperative Research and Development (R\&D) Subsidies Stimulate Regional Innovation Efficiency? Evidence from Germany', Regional Studies, 49(7), pp. 1087-1110.

Broekel, T., Brenner, T. and Buerger, M. (2015) 'An Investigation of the Relation between Cooperation Intensity and the Innovative Success of German Regions', Spatial Economic Analysis, 10(1), pp. 52-78.

Broekel, T., Brachert, M., Duschl, M., and Brenner, T. (2017) ‘Joint R\&D Subsidies, Related Variety, and Regional Innovation', International Regional Science Review, 40(3), pp. 297-326.

Bronzini, R. and Piselli, P. (2009) 'Determinants of long-run regional productivity with geographical spillovers: The role of R\&D, human capital and public infrastructure', Regional Science and Urban Economics, 39(2), pp. 187-199.

Cannone, G. and Ughetto, E. (2014) 'Funding Innovation at Regional Level: An Analysis of a Public Policy Intervention in the Piedmont Region', Regional Studies, 48(2), pp. 270-283. 
Cantner, U., Giebler, A., Günther, J., Kristalova, M. and Meder, A. (2018) ‘Innovation cooperation in East and West Germany: a study on the regional and technological impact', International Journal of Computational Economics and Econometrics, 8(3/4), pp. 242-279.

Capello, R. and Kroll, H. (2016) 'From theory to practice in smart specialization strategy: emerging limits and possible future trajectories', European Planning Studies, 24(8), pp. 1393-1406.

Carree, M.A. and Thurik, A.R. (2008) 'The Lag Structure of the Impact of Business Ownership on Economic Performance in OECD Countries', Small Business Economics, 30(1), pp. 101-110.

Castellacci, F. and Natera, J.M. (2013) 'The dynamics of national innovation systems: A panel cointegration analysis of the coevolution between innovative capability and absorptive capacity', Research Policy, 42(3), pp. 579-594.

Cooke, P., Asheim, B.T., Boschma, R., Schwartz, D. and Tödling, F. (eds.) (2011) Handbook of regional innovation and growth. Cheltenham: Edward Elgar.

Cowan, R. (2000) 'The explicit economics of knowledge codification and tacitness', Industrial and Corporate Change, 9(2), pp. 211-253.

Dettmann, E., Dominguez Lacasa, I., Günther, J. and Jindra, B. (2016) 'The Importance of Localized Related Variety for International Diversification of Corporate Technology', Regional Studies, 50(10), pp. $1648-1662$.

Diebolt, C. and Hippe, R. (2019) 'The long-run impact of human capital on innovation and economic development in the regions of Europe', Applied Economics, 51(5), pp. 542-563.

Edler, J. and Fagerberg, J. (2017) 'Innovation policy: what, why, and how', Oxford Review of Economic Policy, 33(1), pp. 2-23.

Égert, B. (2016) 'Regulation, Institutions, and Productivity: New Macroeconomic Evidence from OECD Countries', American Economic Review, 106(5), pp. 109-113.

Eickelpasch, A. and Fritsch, M. (2005) 'Contests for cooperation--A new approach in German innovation policy', Research Policy, 34(8), pp. 1269-1282. 
Engle, R.F. and Granger, C.W.J. (1987) 'Co-Integration and Error Correction: Representation, Estimation, and Testing,, Econometrica, 55(2), p. 251.

Fiore, A., Grisorio, M.J. and Prota, F. (2011) 'Regional Innovation Systems: Which Role for Public Policies and Innovation Agencies? Some Insights from the Experience of an Italian Region', European Planning Studies, 19(8), pp. 1399-1422.

Foray, D. (2015) Smart specialisation: Opportunities and challenges for regional innovation policy. (Regions and cities, 79). London: Routledge.

Fotopoulos, G. and Storey, D.J. (2017) 'Persistence and change in interregional differences in entrepreneurship: England and Wales, 1921-2011', Environment and Planning A: Economy and Space, 49(3), pp. 670-702.

Fritsch, M. (2004) 'Cooperation and the efficiency of regional R\&D activities', Cambridge Journal of Economics, 28(6), pp. 829-846.

Fritsch, M. and Wyrwich, M. (2014) 'The Long Persistence of Regional Levels of Entrepreneurship: Germany, 1925-2005', Regional Studies, 48(6), pp. 955-973.

Fritsch, M. and Wyrwich, M. (2019) Regional Trajectories of Entrepreneurship, Knowledge, and Growth. (40). Cham: Springer International Publishing.

Grossman, G.M. and Helpman, E. (2001) Innovation and growth in the global economy. 7th edn. Cambridge, Mass.: MIT Press.

Guloglu, B. and Tekin, R.B. (2012) 'A Panel Causality Analysis of the Relationship among Research and Development, Innovation, and Economic Growth in High-Income OECD Countries', Eurasian Economic Review, 2(1), pp. 32-47.

Hall, B.H., Mairesse, J. and Mohnen, P. (2010) 'Measuring the returns to R\&D', in Hall, B.H. and Rosenberg, N. (eds.) Handbook of the Economics of Innovation, Volume 2. Burlington: Elsevier Science. 
Jaffe, A.B. and Trajtenberg, M. (2002) Patents, citations, and innovations: A window on the knowledge economy. Cambridge, Mass.: MIT Press.

Johansen, S. (1988) 'Statistical analysis of cointegration vectors', Journal of Economic Dynamics and Control, 12(2-3), pp. 231-254.

Kaufmann, A. and Tödtling, F. (2002) 'How effective is innovation support for SMEs? An analysis of the region of Upper Austria', Technovation, 22(3), pp. 147-159.

Kim, J. and Lee, S. (2015) 'Patent databases for innovation studies: A comparative analysis of USPTO, EPO, JPO and KIPO', Technological Forecasting and Social Change, 92, pp. 332-345.

Lee, K.-J. (2012) 'The coevolution of IT innovation and copyright institutions: The development of the mobile music business in Japan and Korea', The Journal of Strategic Information Systems, 21(3), pp. $245-255$.

Lopez-Rodriguez, J. and Martinez-Lopez, D. (2017) 'Looking beyond the R\&D effects on innovation: The contribution of non-R\&D activities to total factor productivity growth in the EU', Structural Change and Economic Dynamics, 40, pp. 37-45.

Lucas, R.E. (1988) 'On the mechanics of economic development', Journal of Monetary Economics, 22(1), pp. 3-42.

Lynskey, M.J. (2006) 'Transformative technology and institutional transformation: Coevolution of biotechnology venture firms and the institutional framework in Japan', Research Policy, 35(9), pp. 1389-1422.

Marek, P., Titze, M., Fuhrmeister, C. and Blum, U. (2017) 'R\&D collaborations and the role of proximity', Regional Studies, 51(12), pp. 1761-1773.

Marino, M., Lhuillery, S., Parrotta, P. and Sala, D. (2016) ‘Additionality or crowding-out? An overall evaluation of public R\&D subsidy on private R\&D expenditure', Research Policy, 45(9), pp. 17151730.

Marshall, A. (2013) Principles of Economics. Basingstoke: Palgrave Macmillan. 
Mazzucato, M. and Semieniuk, G. (2017) 'Public financing of innovation: new questions', Oxford Review of Economic Policy, 33(1), pp. 24-48.

Mohnen, P. and Hall, B.H. (2013) 'Innovation and Productivity: An Update', Eurasian Business Review, 3(1), pp. 47-65.

Montmartin, B. and Herrera, M. (2015) 'Internal and external effects of R\&D subsidies and fiscal incentives: Empirical evidence using spatial dynamic panel models', Research Policy, 44(5), pp. 1065-1079.

Muller, E., Zenker, A., Hufnagl, M., Héraud, J.-A., Schnabl, E., Makkonen, T. and Kroll, H. (2017) 'Smart specialisation strategies and cross-border integration of regional innovation systems: Policy dynamics and challenges for the Upper Rhine', Environment and Planning C: Politics and Space, 35(4), pp. 684-702.

Norgaard, R.B. (1994) Development betrayed: The end of progress and a coevolutionary revisioning of the future / Richard B. Norgaard. London: Routledge.

OECD (2016) OECD Science, Technology and Innovation Outlook 2016: OECD.

Pesaran, M.H. and Smith, R.P. (1995) 'Estimating long-run relationships from dynamic heterogeneous panels', Journal of Econometrics, 68(1), pp. 79-113.

Pesaran, M.H., Shin, Y. and Smith, R.P. (1999) 'Pooled Mean Group Estimation of Dynamic Heterogeneous Panels', Journal of the American Statistical Association, 94(446), p. 621.

Phillips, P.C.B. and Moon, H.R. (2000) 'Nonstationary panel data analysis: an overview of some recent developments', Econometric Reviews, 19(3), pp. 263-286.

Polanyi, M. (1966) The Tacit Dimension. New York, NY: Anchor.

Rodríguez-Pose, A. and Crescenzi, R. (2008) 'Research and Development, Spillovers, Innovation Systems, and the Genesis of Regional Growth in Europe', Regional Studies, 42(1), pp. 51-67.

Romer, P.M. (1986) 'Increasing Returns and Long-Run Growth’, Journal of Political Economy, 94(5), pp. 1002-1037. 
Romer, P.M. (1990) 'Endogenous Technological Change', Journal of Political Economy, 98(5), S71102.Sanso-Navarro, M. and Vera-Cabello, M. (2018) 'The long-run relationship between R\&D and regional knowledge: the case of France, Germany, Italy and Spain', Regional Studies, 52(5), pp. 619631.

Saxenian, A. (2000) Regional advantage: Culture and competition in Silicon Valley and Route 128. 8th edn. Cambridge, Mass.: Harvard Univ. Press.

Schneider, L., Kubis, A. and Titze, M. (2019) 'Do diasporas affect regional knowledge transfer within host countries? A panel analysis of German R\&D collaborations', Regional Studies, 53(1), pp. 17-29.

Schwartz, M., Peglow, F., Fritsch, M. and Günther, J. (2012) 'What drives innovation output from subsidized R\&D cooperation?-Project-level evidence from Germany', Technovation, 32(6), pp. 358369.

Titze, M., Brachert, M. and Kubis, A. (2014) 'Actors and Interactions-Identifying the Role of Industrial Clusters for Regional Production and Knowledge Generation Activities', Growth and Change, 45(2), pp. 163-190.

van de Ven, A.H. and Garud, R. (1994) 'The coevolution of technical and institutional events in the development of an innovation', in Baum, J.A.C. and Singh, J. (eds.) Evolutionary dynamics of organizations. New York: Oxford University Press, pp. 425-443.

Verhoeven, D., Bakker, J. and Veugelers, R. (2016) 'Measuring technological novelty with patentbased indicators', Research Policy, 45(3), pp. 707-723.

Volberda, H.W. and Lewin, A.Y. (2003) 'Co-evolutionary Dynamics Within and Between Firms: From Evolution to Co-evolution', Journal of Management Studies, 40(8), pp. 2111-2136.

Wang, E.C. (2010) 'Determinants of R\&D investment: The Extreme-Bounds-Analysis approach applied to 26 OECD countries', Research Policy, 39(1), pp. 103-116. 


\section{Appendix}

Table 1A: Overview of variables used in the empirical analysis

\begin{tabular}{|c|c|c|}
\hline Variable & Operationalization & Data source \\
\hline \multicolumn{3}{|l|}{ Dependent variable } \\
\hline $\begin{array}{l}\text { Economic } \\
\text { performance } \\
\text { (GDP) }\end{array}$ & Log of GDP per capita in real prices & Cambridge Econometrics \\
\hline \multicolumn{3}{|l|}{ Independent variables } \\
\hline Innovation subsidies & $\begin{array}{l}\text { Log of public subsidies for all projects } \\
\text { in the field of innovation and } \\
\text { technology; aggregated on ROR level, } \\
\text { per year and per capita in real prices }\end{array}$ & $\begin{array}{l}\text { Public funding statistics } \\
\text { (Förderkatalog) }\end{array}$ \\
\hline Innovation activity & $\begin{array}{l}\text { Log of number of EPO patents, } \\
\text { assigned to ROR by address of the } \\
\text { German inventor(s), aggregated on } \\
\text { ROR level, per year and per capita }\end{array}$ & PATSTAT \\
\hline Human capital & $\begin{array}{l}\text { Log of share of highly qualified } \\
\text { employees over all employees, } \\
\text { aggregated on ROR level, per year }\end{array}$ & $\begin{array}{l}\text { IAB-BHP (Establishment } \\
\text { History Panel of the } \\
\text { Institute for Employment } \\
\text { Research) }\end{array}$ \\
\hline $\begin{array}{l}\text { Entrepreneurial } \\
\text { activity }\end{array}$ & $\begin{array}{l}\text { Log of number of newly founded } \\
\text { companies per ROR and year }\end{array}$ & $\begin{array}{l}\text { IAB-BHP (Establishment } \\
\text { History Panel of the } \\
\text { Institute for Employment } \\
\text { Research) }\end{array}$ \\
\hline
\end{tabular}

Source: own presentation. 
Table 2A: Descriptive statistics of the variables included in the analysis

\begin{tabular}{|c|c|c|c|c|c|c|c|}
\hline \multicolumn{2}{|l|}{ Variable } & \multirow{2}{*}{$\begin{array}{c}\text { Mean } \\
25578.46\end{array}$} & \multirow{2}{*}{$\begin{array}{l}\text { Std. Dev. } \\
6223.181 \\
4934.772 \\
3817.291\end{array}$} & \multirow{2}{*}{$\begin{array}{c}\text { Min } \\
13403.98 \\
18149.54 \\
12497.23\end{array}$} & \multirow{2}{*}{$\begin{array}{l}\text { Max } \\
53122.09 \\
45666 \\
49012.5\end{array}$} & \multicolumn{2}{|c|}{ Observations } \\
\hline $\begin{array}{l}\text { Economic } \\
\text { performance } \\
(\text { GDP) }\end{array}$ & $\begin{array}{l}\text { overall } \\
\text { between } \\
\text { within }\end{array}$ & & & & & $\begin{array}{l}\mathrm{N}= \\
\mathrm{n}= \\
\mathrm{T}=\end{array}$ & $\begin{array}{c}2611 \\
75 \\
34.8\end{array}$ \\
\hline $\begin{array}{l}\text { Innovation } \\
\text { subsidies }\end{array}$ & $\begin{array}{l}\text { overall } \\
\text { between } \\
\text { within }\end{array}$ & 17.29275 & $\begin{array}{l}25.90762 \\
17.26621 \\
19.42233\end{array}$ & $\begin{array}{l}.00607 \\
1.481157 \\
-51.0595\end{array}$ & $\begin{array}{l}476.2163 \\
82.95762 \\
410.5514\end{array}$ & $\begin{array}{l}\mathrm{N}= \\
\mathrm{n}= \\
\mathrm{T}=\end{array}$ & $\begin{array}{c}2529 \\
75 \\
33.7\end{array}$ \\
\hline $\begin{array}{l}\text { Innovation } \\
\text { activity }\end{array}$ & $\begin{array}{l}\text { overall } \\
\text { between } \\
\text { within }\end{array}$ & 2.231784 & $\begin{array}{l}1.70717 \\
1.30995 \\
1.101114\end{array}$ & $\begin{array}{l}0.012841 \\
0.332033 \\
-1.90001\end{array}$ & $\begin{array}{l}9.838541 \\
5.623759 \\
6.981406\end{array}$ & $\begin{array}{l}\mathrm{N}= \\
\mathrm{n}= \\
\mathrm{T}=\end{array}$ & $\begin{array}{c}2611 \\
75 \\
34.8\end{array}$ \\
\hline Human capital & $\begin{array}{l}\text { overall } \\
\text { between } \\
\text { within }\end{array}$ & .0887143 & $\begin{array}{l}.0497915 \\
.0289132 \\
.04067\end{array}$ & $\begin{array}{l}.0152253 \\
.0445895 \\
-.016235\end{array}$ & $\begin{array}{l}.3296743 \\
.1797807 \\
.2386079\end{array}$ & $\begin{array}{l}\mathrm{N}= \\
\mathrm{n}= \\
\mathrm{T}=\end{array}$ & $\begin{array}{c}2625 \\
75 \\
35\end{array}$ \\
\hline $\begin{array}{l}\text { Entrepreneurial } \\
\text { activity }\end{array}$ & $\begin{array}{l}\text { overall } \\
\text { between } \\
\text { within }\end{array}$ & 721.9112 & $\begin{array}{l}782.419 \\
618.0095 \\
484.9667\end{array}$ & $\begin{array}{l}99 \\
217.0286 \\
-1206.49\end{array}$ & $\begin{array}{l}11941 \\
3317.4 \\
9345.511\end{array}$ & $\begin{array}{l}\mathrm{N}= \\
\mathrm{n}= \\
\mathrm{T}=\end{array}$ & $\begin{array}{c}2625 \\
75 \\
35\end{array}$ \\
\hline
\end{tabular}

Source: own calculation.

Explanation: The first row for each variable displays the "overall" statistics, across all years and regions. The second one shows "between" statistics, and takes into account only the cross-sectional dimension of the data with $\mathrm{n}=75$ for all variables. The final row of each variable stands for variation across time. It shows that although there are some missing years, they are few ( $\mathrm{T}$ is close to or equal to 35 for each variable), meaning that our panel is strongly balanced.

Note: For the ease of reading the descriptive statistics, innovation activity is rescaled as a number of patents per 10000 inhabitants. For the same reason, the numbers in the table are presented in non-log form, whereas natural logarithms are used for calculation, as explained in the text. 
Table 3A. Correlation matrix for variables used in the estimations, year 1980 (beginning of the observation period)

\begin{tabular}{|c|c|c|c|c|c|}
\hline & GDP per capita & $\begin{array}{l}\text { Innovation } \\
\text { subsidies }\end{array}$ & $\begin{array}{l}\text { Innovation } \\
\text { activity }\end{array}$ & $\begin{array}{l}\text { Human } \\
\text { capital }\end{array}$ & $\begin{array}{l}\text { Entrepreneurial } \\
\text { activity }\end{array}$ \\
\hline GDP per capita & 1 & & & & \\
\hline Innovation subsidies & $0.576 * * *$ & 1 & & & \\
\hline Innovation activity & $0.478 * * *$ & $0.281 *$ & 1 & & \\
\hline Human capital & $0.711 * * *$ & $0.612 * * *$ & $0.425 * * *$ & 1 & \\
\hline Entrepreneurial activity & $0.618 * * *$ & $0.435 * * *$ & $0.438 * * *$ & $0.587 * * *$ & 1 \\
\hline
\end{tabular}

${ }^{*} p<0.05,{ }^{* *} p<0.01,{ }^{* * *} p<0.001$

Source: own calculation.

Table 4A. Correlation matrix for variables used in the estimations, year 2014 (end of the observation period)

\begin{tabular}{|c|c|c|c|c|c|}
\hline & GDP per capita & $\begin{array}{l}\text { Innovation } \\
\text { subsidies }\end{array}$ & $\begin{array}{l}\text { Innovation } \\
\text { activity }\end{array}$ & $\begin{array}{l}\text { Human } \\
\text { capital }\end{array}$ & $\begin{array}{l}\text { Entrepreneurial } \\
\text { activity }\end{array}$ \\
\hline GDP per capita & 1 & & & & \\
\hline Innovation subsidies & $0.385 * * *$ & 1 & & & \\
\hline Innovation activity & $0.527 * * *$ & $0.263 *$ & 1 & & \\
\hline Human capital & $0.579 * * *$ & $0.687 * * *$ & $0.384 * * *$ & 1 & \\
\hline $\begin{array}{l}\text { Entrepreneurial activity } \\
{ }^{*} p<0.05,{ }^{* *} p<0.01,{ }^{* * *} p<0.001\end{array}$ & $0.460 * * *$ & $0.436 * * *$ & $0.287^{*}$ & $0.728 * * *$ & 1 \\
\hline
\end{tabular}

Source: own calculation 
Figure 1A: Time series for variables used in the analysis (standardized) for selected regions

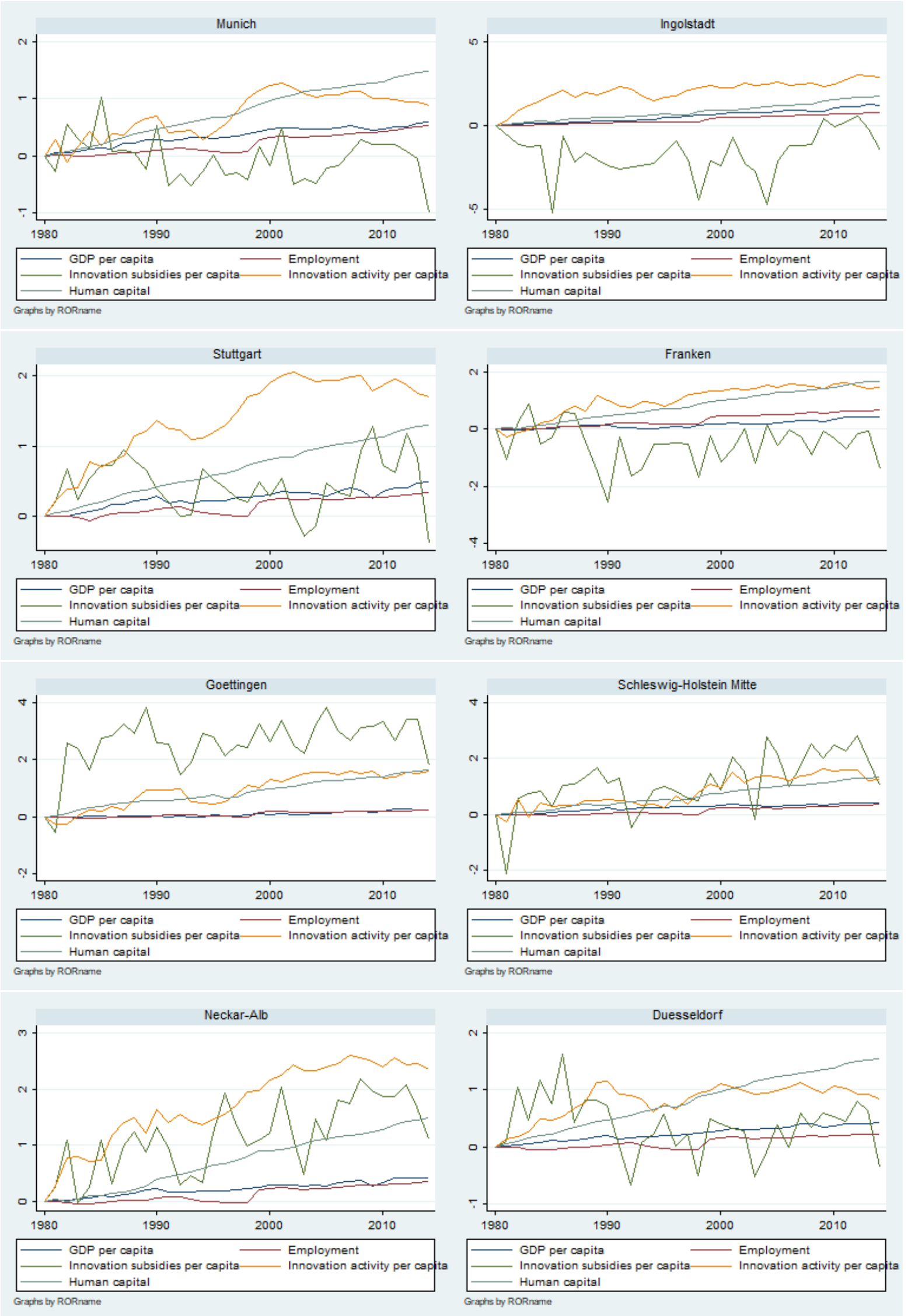

Data source: Cambridge Econometrics, Förderkatalog, PATSTAT. Own calculation. 
Map 1A. Real GDP per capita per planning region (ROR). Comparison between 1980 and 2014.
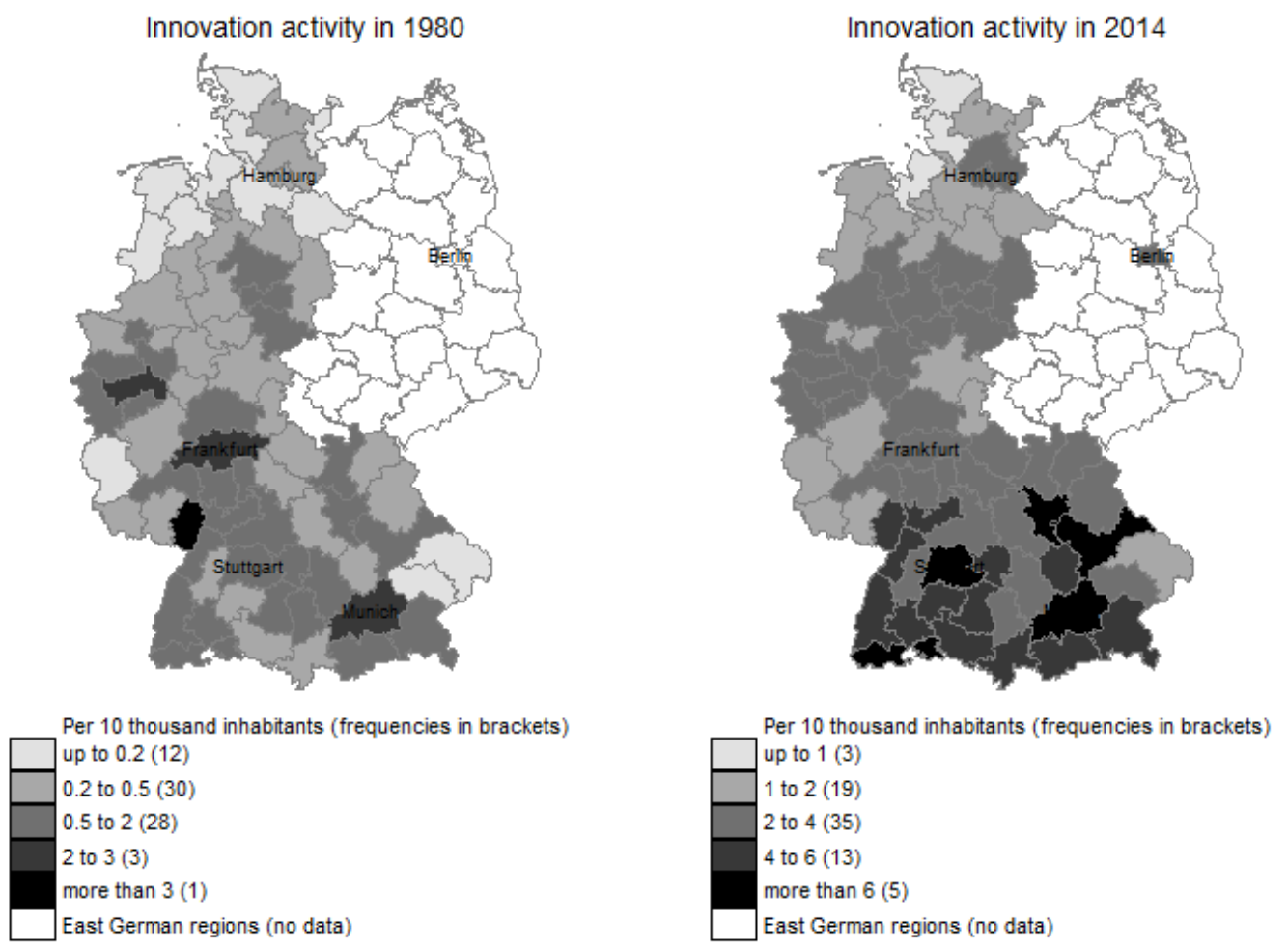

Source: Cambridge econometrics. Own calculations.

Map 2A. Number of patents with at least one German applicant per capita per planning region (ROR). Comparison between 1980 and 2014.
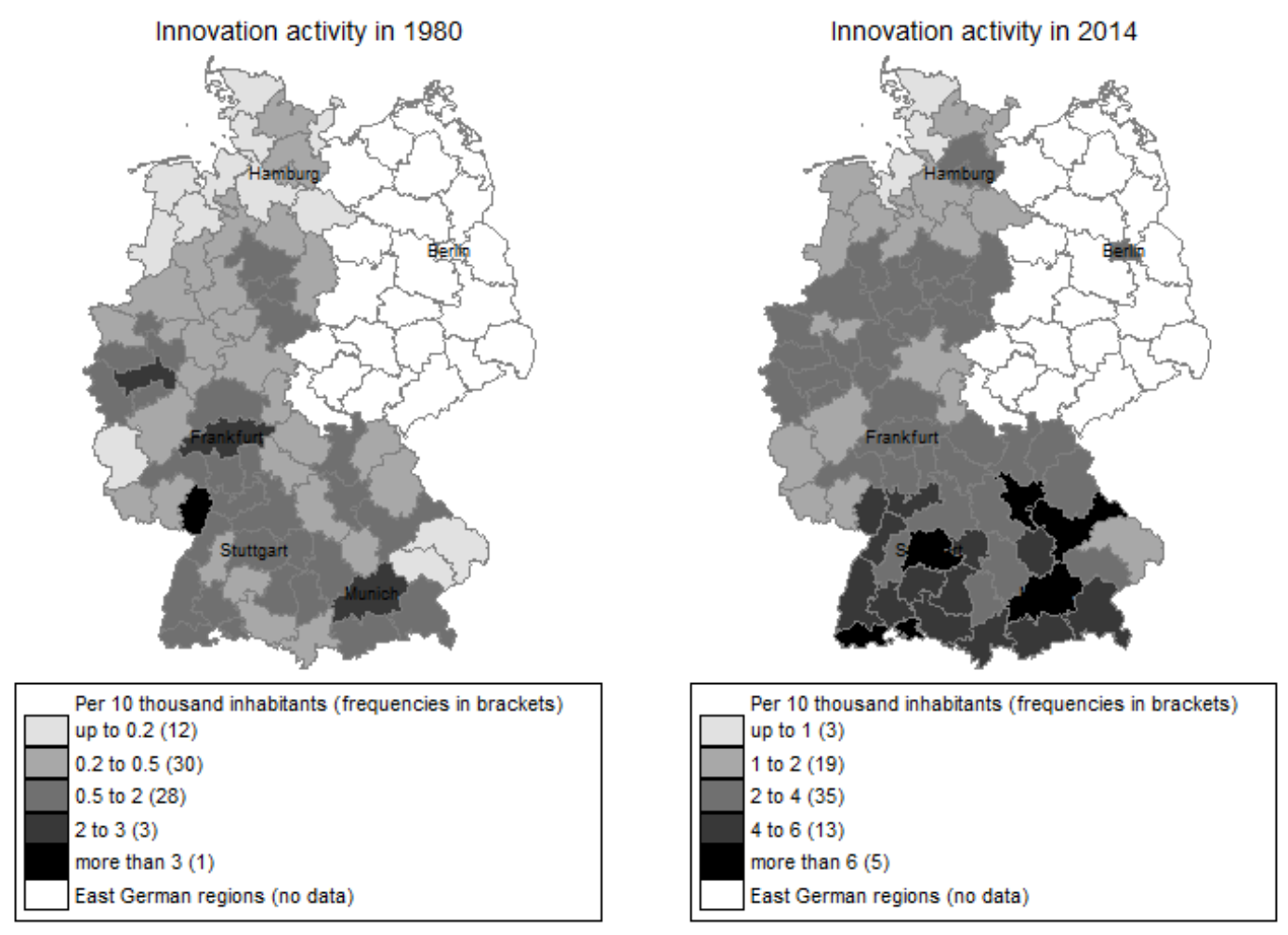

Source: PATSTAT, Cambridge econometrics. Own calculations. 
Map 3A. Share of public innovation subsidies per capita per planning region (ROR). Comparison between 1980 and 2014.
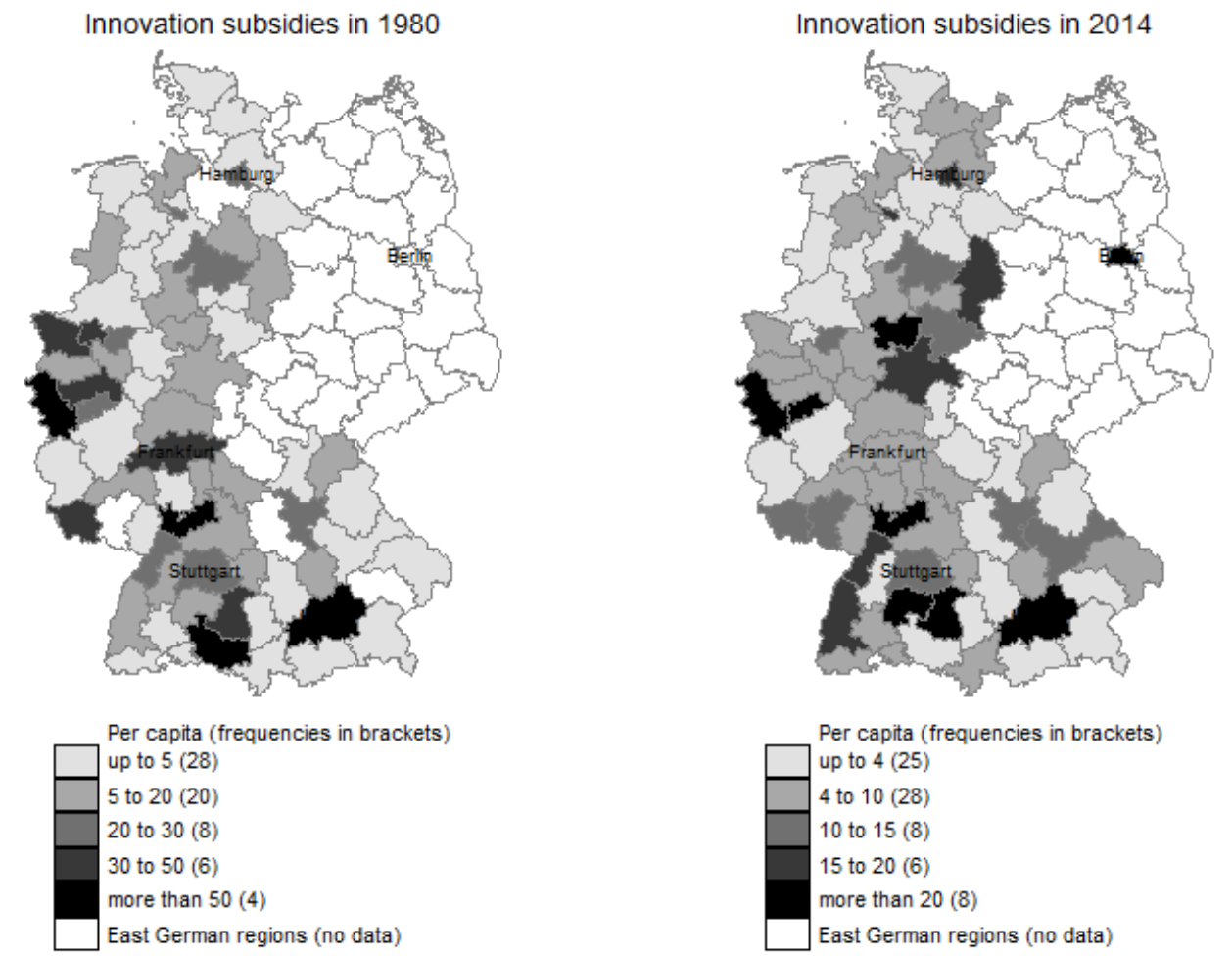

Source: Förderkatalog, Cambridge econometrics. Own calculations. 
Table 5A: Estimation results of different panel cointegration models for the West German planning regions (1980-2014). GDP as a dependant variable.

\begin{tabular}{|c|c|c|c|}
\hline & PMG & $\mathrm{MG}$ & DFE \\
\hline Innovation subsidies & $\begin{array}{c}0.006 * * \\
(2.60)\end{array}$ & $\begin{array}{l}0.008 * \\
(1.95)\end{array}$ & $\begin{array}{l}0.007 \\
(1.30)\end{array}$ \\
\hline Innovation activity & $\begin{array}{c}0.032 * * * \\
(4.47)\end{array}$ & $\begin{array}{c}0.037 * * \\
(2.83)\end{array}$ & $\begin{array}{c}0.044 * * \\
(3.00)\end{array}$ \\
\hline Human capital & $\begin{array}{c}0.240 * * * \\
(29.32)\end{array}$ & $\begin{array}{c}0.258 * * * \\
(18.15)\end{array}$ & $\begin{array}{c}0.221 * * * \\
(11.78)\end{array}$ \\
\hline Entrepreneurial activity & $\begin{array}{l}-0.001 \\
(-0.14)\end{array}$ & $\begin{array}{l}-0.015 \\
(-1.52)\end{array}$ & $\begin{array}{l}0.014 \\
(0.78)\end{array}$ \\
\hline Speed of adjustment & $\begin{array}{c}-0.295^{* * *} \\
(-14.64)\end{array}$ & $\begin{array}{c}-0.582 * * * \\
(-18.27)\end{array}$ & $\begin{array}{c}-0.206^{* * *} \\
(-16.91) \\
\end{array}$ \\
\hline SR Innovation subsidies & $\begin{array}{l}0.000 \\
(0.09)\end{array}$ & $\begin{array}{l}-0.001 \\
(-0.89)\end{array}$ & $\begin{array}{l}0.001 \\
(0.78)\end{array}$ \\
\hline SR Innovation activity & $\begin{array}{c}0.020 * * * \\
(4.35)\end{array}$ & $\begin{array}{c}0.010 * * \\
(1.96)\end{array}$ & $\begin{array}{c}0.011 * * \\
(2.89)\end{array}$ \\
\hline SR Human capital & $\begin{array}{l}0.009 \\
(0.43)\end{array}$ & $\begin{array}{l}-0.023 \\
(-0.95)\end{array}$ & $\begin{array}{l}0.026 \\
(1.10)\end{array}$ \\
\hline SR Entrepreneurial activity & $\begin{array}{c}-0.007 * * \\
(-2.79)\end{array}$ & $\begin{array}{l}-0.001 \\
(-0.48)\end{array}$ & $\begin{array}{c}-0.007 * * \\
(-2.48)\end{array}$ \\
\hline Constant term & $\begin{array}{c}3.257 * * * \\
(14.62)\end{array}$ & $\begin{array}{c}6.599 * * * \\
(16.98)\end{array}$ & $\begin{array}{c}2.275^{* * *} * \\
(15.86)\end{array}$ \\
\hline $\begin{array}{l}\text { No. of obs } \\
\text { BIC } \\
\text { Log pseudolikelihood }\end{array}$ & $\begin{array}{c}2400 \\
-10130 \\
5104 \\
\end{array}$ & $\begin{array}{c}2400 \\
-10794 \\
5436 \\
\end{array}$ & . \\
\hline Hausman test & 0.2741 & & \\
\hline
\end{tabular}


Table 6A: Estimation results of the panel cointegration model for West German planning regions (1984-2014). GDP as a dependant variable. Top performers.

\begin{tabular}{|c|c|c|c|}
\hline & PMG & $\mathrm{MG}$ & DFE \\
\hline Innovation subsidies & $\begin{array}{c}0.009 * * \\
(2.93)\end{array}$ & $\begin{array}{l}0.009^{*} \\
(1.86)\end{array}$ & $\begin{array}{l}0.011^{*} \\
(1.68)\end{array}$ \\
\hline Innovation activity & $\begin{array}{l}0.042 * * * \\
(5.48)\end{array}$ & $\begin{array}{c}0.039 * * \\
(2.46)\end{array}$ & $\begin{array}{c}0.049 * * \\
(2.73)\end{array}$ \\
\hline Human capital & $\begin{array}{c}0.243 * * * \\
(29.57)\end{array}$ & $\begin{array}{c}0.264 * * * \\
(16.41)\end{array}$ & $\begin{array}{c}0.236^{* * *} \\
(10.75)\end{array}$ \\
\hline Entrepreneurial activity & $\begin{array}{l}-0.001 \\
(-0.08)\end{array}$ & $\begin{array}{l}-0.012 \\
(-1.24)\end{array}$ & $\begin{array}{l}0.007 \\
(0.34)\end{array}$ \\
\hline Speed of adjustment & $\begin{array}{c}-0.308 * * * \\
(-12.50)\end{array}$ & $\begin{array}{c}-0.587 * * * \\
(-18.74)\end{array}$ & $\begin{array}{c}-0.201 * * * \\
(-14.51)\end{array}$ \\
\hline $\begin{array}{l}\text { SR Innovation subsidies per } \\
\text { capita }\end{array}$ & $\begin{array}{l}-0.001 \\
(-0.48)\end{array}$ & $\begin{array}{l}-0.002 \\
(-0.92)\end{array}$ & $\begin{array}{l}0.000 \\
(0.15)\end{array}$ \\
\hline SR Innovation activity & $\begin{array}{c}0.026 * * * \\
(4.55)\end{array}$ & $\begin{array}{c}0.017 * * \\
(2.78)\end{array}$ & $\begin{array}{c}0.021 * * * \\
(4.21)\end{array}$ \\
\hline SR Human capital & $\begin{array}{l}0.021 \\
(0.89)\end{array}$ & $\begin{array}{l}-0.025 \\
(-0.92)\end{array}$ & $\begin{array}{c}0.052 * \\
(1.81)\end{array}$ \\
\hline SR Entrepreneurial activity & $\begin{array}{c}-0.008 * * * \\
(-3.53)\end{array}$ & $\begin{array}{l}-0.004 \\
(-1.44)\end{array}$ & $\begin{array}{c}-0.007 * * \\
(-2.13)\end{array}$ \\
\hline Constant term & $\begin{array}{c}3.427 * * * \\
(12.47)\end{array}$ & $\begin{array}{c}6.655^{* * *} \\
(17.99)\end{array}$ & $\begin{array}{c}2.239^{* * *} \\
(13.68)\end{array}$ \\
\hline No. of obs & 1838 & 1838 & \\
\hline $\mathrm{BIC}$ & -7702 & -8171 & . \\
\hline Log pseudolikelihood & 3889 & 4123 & \\
\hline Hausman test & 0.0157 & & \\
\hline
\end{tabular}


${ }^{\mathrm{i}}$ Prior to the German re-unification, no comparable data sources for the chosen variables existed in the former German Democratic Republic (GDR). Therefore, it is not possible to extend the analysis to Germany as a whole. Available data, starting 1995, are not sufficient for our study.

ii The "Förderkatalog" is a unique source freely available to identify the type and volume of direct project funding by the German government (https://foerderportal.bund.de/foekat/jsp/StartAction.do?actionMode=list). Several studies in regional economics use it, such as Broekel (2015); Broekel et al. (2017); Marek et al. (2017); Titze et al., (2014); Schneider et al., (2019).

iii The German Research Foundation (DFG) funds basic research projects that are not in the database, just like institutional funding of universities and research institutes.

${ }^{\text {iv }}$ Maps 1A, 2A and 3A in the Appendix allows for a comparison of the level of all three main variables for the beginning (1980) and the end of the observation period (2014).

${ }^{v}$ Illustrations of all regions are available on request.

${ }^{\text {vi }}$ Standard panel models like fixed effects or dynamic panel estimators such as the Arellano-Bond-GMM often produce inconsistent and potentially misleading results for panels with a large number of observation periods, since the assumptions of homogeneous slope coefficients and error variances are not appropriate (Pesaran et al., 1999; Phillips and Moon, 2000).

${ }^{\text {vii }}$ As a robustness check, we also report specifications estimated with the help of a dynamic fixed-effects (DFE) model. However, as mentioned above, these models assume slope homogeneity across all regions, which makes the results not very reliable in case of a certain degree of heterogeneity.

viii As a robustness check, we implement a lag specification commonly used in empirical literature (see e. g. Castellacci and Natera (2013) or Wang (2010)) with the same delay for all variables of one year (see Appendix).

${ }^{\text {ix }}$ For the estimation we use the Stata command XTPMG of Blackburne and Frank (2007).

${ }^{x}$ We look at the so called "top performer" sample within the setting of the ARDL specification $(1,1,1,1,1)$, which we use as a robustness check for our main models that have a more complex lag structure. 